\title{
The feasibility of age-specific travel restrictions during influenza pandemics
}

Elson HY Lam¹, Benjamin J Cowling ${ }^{1}$, Alex R Cook ${ }^{2,3,4}$, Jessica YT Wong ${ }^{1}$, Max SY Lau ${ }^{1}$ and Hiroshi Nishiura ${ }^{1,5^{*}}$

\footnotetext{
* Correspondence: nishiura@hku.hk 'School of Public Health, The University of Hong Kong, Level 6, Core F, Cyberport 3, 100 Cyberport Road, Pokfulam, Hong Kong, People's Republic of China Full list of author information is available at the end of the article
}

\begin{abstract}
Background: Epidemiological studies have shown that imposing travel restrictions to prevent or delay an influenza pandemic may not be feasible. To delay an epidemic substantially, an extremely high proportion of trips ( 99\%) would have to be restricted in a homogeneously mixing population. Influenza is, however, strongly influenced by age-dependent transmission dynamics, and the effectiveness of agespecific travel restrictions, such as the selective restriction of travel by children, has yet to be examined.

Methods: A simple stochastic model was developed to describe the importation of infectious cases into a population and to model local chains of transmission seeded by imported cases. The probability of a local epidemic, and the time period until a major epidemic takes off, were used as outcome measures, and travel restriction policies in which children or adults were preferentially restricted were compared to age-blind restriction policies using an age-dependent next generation matrix parameterized for influenza H1N1-2009.

Results: Restricting children from travelling would yield greater reductions to the short-term risk of the epidemic being established locally than other policy options considered, and potentially could delay an epidemic for a few weeks. However, given a scenario with a total of 500 imported cases over a period of a few months, a substantial reduction in the probability of an epidemic in this time period is possible only if the transmission potential were low and assortativity (i.e. the proportion of contacts within-group) were unrealistically high. In all other scenarios considered, age-structured travel restrictions would not prevent an epidemic and would not delay the epidemic for longer than a few weeks.

Conclusions: Selectively restricting children from traveling overseas during a pandemic may potentially delay its arrival for a few weeks, depending on the characteristics of the pandemic strain, but could have less of an impact on the economy compared to restricting adult travelers. However, as long as adults have at least a moderate potential to trigger an epidemic, selectively restricting the higher risk group (children) may not be a practical option to delay the arrival of an epidemic substantially.
\end{abstract}

(c) 2011 Lam et al; licensee BioMed Central Ltd. This is an Open Access article distributed under the terms of the Creative Commons Attribution License (http://creativecommons.org/licenses/by/2.0), which permits unrestricted use, distribution, and reproduction in any medium, provided the original work is properly cited. 


\section{Background}

Long-distance international flights facilitate human movement, enhancing not only crossborder travel but also the global spread of infectious diseases. The well-connected global airline network allows multiple importations of infected individuals and rapid dissemination of an epidemic to a previously disease-free country [1], as was observed during the influenza H1N1-2009 pandemic [2-4]. Border controls aim to identify and restrict movement of infected and/or infectious individuals at the border, thereby lessening the untraced importation of infection from a source country. One such border control measure is to impose restrictions on travel that radically cut traveler numbers, a potentially effective option during the early stage of a pandemic. Perhaps because a large-scale restriction policy presents political and economic difficulties to our highly connected global society, long-lasting and large-scale mandatory restriction did not take place during the H1N1-2009 pandemic.

Prior to the H1N1-2009 pandemic, several studies assessed the effectiveness of travel restrictions [5-10], but none was equivocal in supporting it to be used, for two major reasons. First, if the epidemic is already established overseas, there will be a continuous exportation of cases, which will eventually allow the epidemic to establish a foothold in the country in question regardless of the presence of control efforts. As a result, travel restrictions could only delay the arrival of the epidemic, perhaps for weeks or months [7]. Second, even though travel restrictions may effect a delay, several published studies agree that the epidemic can only be delayed substantially if an implausibly high ( $99 \%)$ proportion of trips are prevented [8-10]. The public health effort that is required to restrict $99 \%$ of travelers may not be too different from that of completely shutting down the border, and such an extreme restriction may not be feasible due to its impact on world trade and economic activity. In addition, the benefit, i.e. a brief delay before widespread community transmission, might not warrant the costs of travel restrictions [11]. The revised International Health Regulations, issued by the World Health Organization in 2005, emphasizes the need to avoid unnecessary interference with international traffic and trade [12]. The combination of scientific evidence of poor effectiveness, the large prospective economic impact, and international law have thus made policies that impose blanket travel restriction policies unfeasible.

Epidemiological studies of the influenza H1N1-2009 pandemic have revealed that transmission was highly heterogeneous and mainly maintained by school-age children [13-17]. However, international travel is usually dominated by adults, and consequently imported cases have also been dominated by adults [18]. In a previous study [19], a multivariate stochastic model was employed to examine the age-related impact of imported cases on the establishment of a major epidemic, which suggested that the predominance of adult travelers might delay the arrival of an epidemic with the same characteristics as the 2009 pandemic. This combination of age-assortative mixing, more infection among children, and greater volume of travel among adults raises the question: how effective would selective age-specific travel restrictions, that target child travelers, be? Although restricting adult international travel may be economically damaging, the impact of preventing child travel, by cancelling school trips for instance, is likely to be less severe. The purpose of the present study is to examine the potential effectiveness of age-specific selective travel restriction against an influenza pandemic with similar characteristics to that of the 2009 pandemic, using a parsimonious statistical model. 


\section{Methods}

\section{Theoretical basis and hypothetical settings}

Empirical observations of the H1N1-2009 pandemic support the hypothesis that agespecific travel restrictions could be effective. Table 1 lists countries that reported initial imported cases in children. Although it is known that adults were predominant among imported cases, children were also among the first identified imported cases in many countries. Table 2 shows countries in which initial or almost initial local cases were observed among children (e.g. school outbreaks). Undetected imported infections in children may have fueled some of the initial school outbreaks, and again the restriction of child movement may have the potential to prevent those clusters. These observations justify our motivation to investigate the effectiveness of child movement restrictions in reducing the risk of an epidemic and delaying an epidemic.

Employing a simple statistical model, we assess the effectiveness of travel reduction during the first 50 days of a pandemic, roughly corresponding to the time period in which enhanced surveillance was conducted in 2009 (e.g. in Japan [14,20]). We consider a case study modeled on the H1N1-2009 pandemic in Hong Kong, a special administrative region of the People's Republic of China, during the early epidemic period. From 1 May to 19 July 2009, there were 113 confirmed imported cases in Hong Kong [19] with a daily average of 2 cases. Assuming that approximately $30 \%$ of infected travelers were identified [21], and ignoring the initial linear increase in the rate of growth number of new imported cases for the first 50 days coupled with a sampling of infected travelers

Table 1 Countries initially reporting child imported cases during influenza pandemic (H1N1-2009)

\begin{tabular}{|c|c|c|}
\hline Country & $\begin{array}{l}\text { Report } \\
\text { month }\end{array}$ & Descriptions \\
\hline Australia [36] & May 2009 & $\begin{array}{l}\text { The first confirmed Victorian case was reported in a child returning from } \\
\text { USA }\end{array}$ \\
\hline Argentina [37] & $\begin{array}{l}\text { March } \\
2010\end{array}$ & First case detected in Chile's Quake-hit area was a 5-year old child \\
\hline Brazil [38] & May 2009 & $\begin{array}{l}\text { The first four imported cases were found in young adults who had travelled } \\
\text { to Mexico and the USA }\end{array}$ \\
\hline China [39] & May 2009 & $\begin{array}{l}\text { The first imported case was a student returning from Canada. The second } \\
\text { and third imported cases were notified in students coming from USA }\end{array}$ \\
\hline Ecuador [40] & May 2009 & First case of H1N1-2009 was a student aged 13 returning from the USA \\
\hline France $[41]$ & May 2009 & Second imported case was a student aged 17 from Mexico \\
\hline Italy [42] & May 2009 & $\begin{array}{l}\text { A 11-year-old male child and a 33-month-old infant were confirmed to be } \\
\text { the first and third cases of H1N1-2009 in Rome }\end{array}$ \\
\hline Japan [43] & May 2009 & $\begin{array}{l}\text { Three teenage students and a teacher were confirmed to be the first four } \\
\text { imported H1N1-2009 cases after returning from a school trip in Canada }\end{array}$ \\
\hline New Zealand [44] & April 2009 & $\begin{array}{l}\text { The first imported cases in New Zealand arrived in a group of students } \\
\text { returning from a visit to Mexico }\end{array}$ \\
\hline Portugal $[45]$ & June 2009 & Third imported case was a 8-year-old child returning from Toronto \\
\hline Singapore $[46]$ & June 2009 & $\begin{array}{l}\text { Eighth case is a } 15 \text {-year-old Singaporean male who travelled from India to } \\
\text { Orlando and Atlanta }\end{array}$ \\
\hline Spain [47] & July 2009 & $\begin{array}{l}13 \text { cases of influenza evacuated from a camp in La Vera. Of the } 13 \text { cases, } 11 \\
\text { were children }\end{array}$ \\
\hline Thailand [48] & May 2009 & $\begin{array}{l}\text { First imported case was a 17-year-old Thai female student returning from } \\
\text { Mexico }\end{array}$ \\
\hline $\begin{array}{l}\text { United Kingdom } \\
\text { [49] }\end{array}$ & April 2009 & First confirmed case, a pupil at a school in England, was imported \\
\hline $\begin{array}{l}\text { United States of } \\
\text { America [50] }\end{array}$ & April 2009 & First two cases were identified in two children in California \\
\hline
\end{tabular}


Table 2 Countries with early child clusters of cases (or school outbreaks) during the influenza pandemic (H1N1-2009)

\begin{tabular}{|c|c|c|}
\hline Country & $\begin{array}{l}\text { Report } \\
\text { month }\end{array}$ & Descriptions \\
\hline Australia [51] & $\begin{array}{l}\text { February } \\
2010\end{array}$ & $\begin{array}{l}\text { The return of children to school in the North American autumn } 2009 \text { was } \\
\text { associated with a substantial increase in the number of cases of pandemic } \\
\text { H1N1 } 2009 \text { influenza }\end{array}$ \\
\hline Australia [52] & May 2009 & $\begin{array}{l}55 \% \text { of } \mathrm{H} 1 \mathrm{~N} 1-2009 \text { cases in Australia and } 63 \% \text { of cases in Victoria to date } \\
\text { have been school aged children ( } 5-17 \text { years) }\end{array}$ \\
\hline Argentina [53] & May 2009 & $\begin{array}{l}\text { First imported case seeded an elementary school outbreak in Buenos Aires, } \\
\text { and, within days, several schools reported increasing numbers of cases }\end{array}$ \\
\hline Cyprus [54] & June 2009 & $\begin{array}{l}\text { The disease spread quickly, initially among younger people who visited } \\
\text { tourist resorts and entertainment clubs or school-aged children who stayed } \\
\text { at camping places or summer schools }\end{array}$ \\
\hline France [55] & July 2009 & $\begin{array}{l}\text { The first time in France, a confirmed outbreak without history of travel } \\
\text { occurred in a secondary school in Toulouse district }\end{array}$ \\
\hline Germany [56] & June 2009 & $\begin{array}{l}\text { About two thirds of indigenous cases were associated with two large } \\
\text { school-associated outbreaks }\end{array}$ \\
\hline Italy [42] & $\begin{array}{l}\text { December } \\
2009\end{array}$ & $\begin{array}{l}\text { First cluster of in-country transmission involved a 33-month-old and a 11- } \\
\text { year-old child }\end{array}$ \\
\hline Japan [57] & May 2009 & Most of new cases were seen in high school students in western Japan \\
\hline Macau [58] & July 2009 & Three locally-infected cases were all local primary school students \\
\hline Malaysia [59] & July 2009 & $\begin{array}{l}\text { The first case was a student returning from the US followed by multiple } \\
\text { clusters in schools, which all involved cases returning from abroad with the } \\
\text { infection. }\end{array}$ \\
\hline Thailand [48] & $\begin{array}{l}\text { October } \\
2009\end{array}$ & $\begin{array}{l}\text { The number of reported cases was most prevalent in primary school } \\
\text { students aged 6-12 years, followed by secondary school students aged 13- } \\
18 \text { years }\end{array}$ \\
\hline $\begin{array}{l}\text { United Kingdom } \\
\text { [49] }\end{array}$ & $\begin{array}{l}\text { August } \\
2009\end{array}$ & $\begin{array}{l}\text { First confirmed case, a pupil at a school in England, was imported. During } \\
\text { the following two weeks, } 16 \text { further cases were confirmed with } \\
\text { epidemiological links to the first imported case. }\end{array}$ \\
\hline $\begin{array}{l}\text { United States of } \\
\text { America [60] }\end{array}$ & $\begin{array}{l}\text { October } \\
2009\end{array}$ & $\begin{array}{l}\text { In May 2009, one of the earliest outbreaks of } 2009 \text { pandemic influenza A } \\
\text { virus (pH1N1) infection resulted in the closure of a semi-rural Pennsylvania } \\
\text { elementary school }\end{array}$ \\
\hline
\end{tabular}

from local cases, we expect a daily average of 10 imported cases. Since we consider a 50 day time horizon, this extrapolates to 500 imported cases in this hypothetical scenario. Given that more than $60 \%$ of confirmed cases were adults [18], we assume that children and adults comprise of $30 \%$ and $70 \%$ of the total of imported cases, respectively. In other words, everyday there are $n_{\mathrm{c}}=3$ child cases and $n_{\mathrm{a}}=7$ adult cases imported, and over 50 days, there would be $N_{\mathrm{c}}=150$ child and $N_{\mathrm{a}}=350$ adult imported cases. It should be noted that the proportion of children among all international travelers is about $10 \%$ (e.g. those aged below 20 accounted for 10.4\% of all legal immigrations in Japan, 2010 [22]), that is, less than the proportion of imported child cases. This indicates that, under our hypothetical scenario with stationary importation, the risk of influenza among child travelers is approximately fourfold that of adult travelers (i.e. $(0.3 / 0.1) \times(0.9 / 0.7)=3.86$ ), and also that restricting child travel is 4 times more likely to prevent an entry of influenza case than restricting adult travel. Connecting flights from Mexico City to Hong Kong take longer than 27 hours, and considering additional times from home/hotel to airport, we assume that a time lag of $\delta=2$ days from infection until the case starts influencing local transmission in Hong Kong.

\section{Modelling methods}

We use two outcome measures to quantify the effectiveness of selective travel restrictions. The first is the probability of an epidemic, defined as the probability of observing 
a major epidemic, that is, an epidemic not going extinct by chance [23]. The second uses the time required for a major epidemic to take place, conditional on non-extinction in the short term, to quantify the delay effect, i.e., the difference in the timing of epidemic overshoot between scenarios in the presence and absence of selective travel restrictions.

To model age-dependent transmission dynamics, we employ the two-by-two next generation matrix $\mathbf{K}$ which describes within- and between-group transmissions in a population that consists of children and adults. Throughout this article, we label children as type $c$ and adults as type $a$. Let $R_{\mathrm{ij}}$ denote the average number of secondary cases in hosts of type $i$ generated by a single infected individual of host type $j$. We assume the offspring distribution to be Poisson, and adopt a previously studied parametric form $([13,19])$, i.e.

$$
R_{i j} \propto\left\{\begin{array}{l}
(1-\theta) \alpha_{i} \beta_{j} q_{i} \text { for } i \neq j, \\
\theta \alpha_{i} \beta_{j}+(1-\theta) \alpha_{i} \beta_{j} q_{i}
\end{array} \text { for } i=j,\right.
$$

where $q_{\mathrm{i}}$ is the relative size of the subpopulation $i$ (i.e., $q_{\mathrm{c}}+q_{\mathrm{a}}=1$ ), $\alpha_{\mathrm{i}}$ and $\beta_{\mathrm{j}}$ represent age-specific susceptibility and infectiousness of hosts of type $i$ and $j$ respectively, while $\theta$ is an assortativity coefficient representing the proportion of contacts reserved for within-group mixing (and $(1-\theta)$ represents the proportion of contacts subject to random or proportionate mixing). As the baseline setting, parameters are fixed at $q_{\mathrm{c}}=0.32, \alpha_{\mathrm{c}}=$ 2.06, $\alpha_{\mathrm{a}}=\beta_{\mathrm{c}}=\beta_{\mathrm{a}}=1$, and $\theta=0.50$ [13]. The dominant eigenvalue of $\mathbf{K}$ gives the reproduction number $R$. Given that empirical estimates of $R$ for H1N1-2009 ranged from 1.2 to 2.3 by limiting the choice of mean generation time [24], we examine three different values of the reproduction number, 1.2, 1.6 and 2.0 to account for relevant uncertainty in the transmission potential of a pandemic. For each $R$, we rescale the next generation matrix by

$$
\mathbf{M}=\frac{R}{\rho(\mathbf{K})} \mathbf{K}
$$

where $\rho($.$) denotes the dominant eigenvalue. We use the rescaled \mathbf{M}$ for all calculations.

\section{The risk of an outbreak under targeted travel restrictions}

We follow a previous study [19], adopting linear approximation of the growth of cases during the early phase of an epidemic. That is, we calculate the probabilities $\pi_{c}$ and $\pi_{a}$ of extinction given a single infected child or adult, respectively, by iteratively solving the following equations:

$$
\begin{aligned}
& \pi_{c}=\frac{1}{1+R_{c c}\left(1-\pi_{c}\right)+R_{a c}\left(1-\pi_{a}\right)}, \\
& \pi_{a}=\frac{1}{1+R_{c a}\left(1-\pi_{c}\right)+R_{a a}\left(1-\pi_{a}\right)} .
\end{aligned}
$$

The solution rests on a homogeneous birth-and-death process, and its derivation can be found elsewhere [25]. We explicitly account for the delay in infection-age among imported cases [3], that is, that imported cases must have been infected prior to arrival in Hong Kong. A slight delay, even of a fraction of a day, is not negligible in the 
natural history of an acute illness such as influenza [26]. For simplicity, we assume that there was a constant delay of $\delta=2$ days between infection and arrival for all imported cases. Let $k_{\mathrm{c}}$ and $k_{\mathrm{a}}$ be the number of imported infections among children and adults, respectively, in Hong Kong that are capable of causing on secondary transmission. To facilitate the calculation of the probability of extinction above, we assume that the generation time of influenza is exponentially distributed with mean $1 / \gamma=3$ days [19]. Given $N_{\mathrm{c}}$ and $N_{\mathrm{a}}$ child and adult imported cases, the probability that $m_{\mathrm{c}}$ and $m_{\mathrm{a}}$ local index cases will result is

$$
\begin{aligned}
& \operatorname{Pr}\left(m_{j}=s\right)=\sum_{k_{a}=0}^{N_{a}} \sum_{k_{c}=0}^{N_{c}}\left(\begin{array}{l}
N_{c} \\
k_{c}
\end{array}\right) \exp \left(-\gamma k_{c} \delta\right)[1-\exp (-\gamma \delta)]^{N_{c}-k_{c}} \\
& \times\left(\begin{array}{c}
N_{a} \\
k_{a}
\end{array}\right) \exp \left(-\gamma k_{a} \delta\right)[1-\exp (-\gamma \delta)]^{N_{a}-k_{a}} \\
& \times\left(k_{c} \exp (-\gamma \delta) R_{j c}+k_{a} \exp (-\gamma \delta) R_{j a}\right)^{s} \\
& \times \frac{\exp \left(-k_{c} \exp (-\gamma \delta) R_{j c}-k_{a} \exp (-\gamma \delta) R_{j a}\right)}{s !}
\end{aligned}
$$

for $j=c$ or $a$ [9]. The first two binomial terms account for the probability that child and adult imported cases arrive in Hong Kong while still infectious, while the last, Poisson, term describes the probability that those infectious imported cases generate $m_{\mathrm{c}}\left(\right.$ or $m_{\mathrm{a}}$ ) local index cases. As a result, the probability of an epidemic is

$$
\operatorname{Pr}(\text { epidemic })=1-\sum_{s_{c}=0}^{\infty} \operatorname{Pr}\left(m_{c}=s_{c}\right) \pi_{c}^{s_{c}} \sum_{s_{a}=0}^{\infty} \operatorname{Pr}\left(m_{a}=s_{a}\right) \pi_{a}^{s_{a}} .
$$

By varying the total number of child and adult travelers $N_{\mathrm{c}}$ and $N_{\mathrm{a}}$ as part of a simulated travel restriction policy, we examined the effectiveness of travel restriction in reducing the epidemic risk.

\section{Time taken for a local epidemic to occur under targeted travel restrictions}

Replacing the total numbers of child and adult imported cases for the first 50 days (i.e. $N_{\mathrm{c}}$ and $N_{\mathrm{a}}$ ) in (4) by the daily numbers of child and adult imported cases (i.e. $n_{\mathrm{c}}$ and $n_{\mathrm{a}}$ where $\left.n_{\mathrm{c}}+n_{\mathrm{a}}=10\right)$, we obtain the daily probability $(p)$ that an epidemic is initiated by infection of a local index case on the specified day. The probability of initiation on day $D$ is described by the geometric sequence [27]:

$$
\operatorname{Pr}(D=d)=(1-p)^{d-1} p .
$$

Therefore, the cumulative distribution function of (6) is given by $1-(1-p)^{d}$. We calculated the dates at which the cumulative probability first exceeds $50 \%$ and $95 \%$, that is, the "average" and "latest plausible" times of local epidemic. The delay in epidemic is derived from the difference in the corresponding dates between the baseline scenario (i.e. without travel restriction) and a scenario in which a fraction of the imported cases were restricted from traveling.

We assess the effectiveness of three different travel restriction policies in four scenarios. In scenarios (i) and (ii), travel restrictions are non-targeted and apply to a fraction of all adults and children, while in scenarios (iii) children or (iv) adults are 
preferentially restricted from travel. In scenario (i) mixing is assumed to be homogeneous, while in the other scenarios it is heterogeneous, with age assortativity. For selective restrictions (scenarios iii and iv), once the proportion of all travelers that fall into the restricted age group is passed, at $10 \%$ for children and $90 \%$ for adults, the other age group begins to be targeted.

\section{Sensitivity analysis}

Our results incorporate assortative mixing via the parameter $\theta$, which reflects the proportion of contacts within-group (e.g. child-to-child contacts among the total of contacts made by a single child). If transmission is fully assortative, $\theta=1$, meaning children contact only children, and adults, only adults. If $\theta=0$, it implies random or proportionate mixing. We examined the sensitivity of the effectiveness of selective travel restrictions to the assortativity coefficient. While we adopt a published estimate $\theta=0.50$ at the baseline, we also examined the effectiveness of child-first restriction at $\theta=0.10$ and 0.90 , i.e. plausible but extreme values $[13,19]$. It should be noted that even our baseline value $\theta=0.50$ may be regarded as implausibly high, considering the results of social contact survey based on an arbitrary, socially defined "contact" (e.g. [28]), but we adopted 0.50 because this is only the estimate derived from actual epidemic data [13].

\section{Results}

The probability of an epidemic is shown in Figure 1 as a function of the number of imported cases (ranging from 0 to 100) and the reproduction number with and without accounting for the delay in infection-age among imported cases. In the absence of interventions, the probability of epidemic is greater in homogeneously mixing population (A) than in heterogeneously mixing population (B), but the difference is small and not fully distinguishable unless $R$ is small. Accounting for the delay between infection and arrival at the border, the probability of an epidemic increases with the number of imported cases more slowly than when not accounting for infection-age. However, in both Figures 1A and $1 \mathrm{~B}$, the probability is in general abruptly elevated with increasing number of imported cases, which echoes the findings in past studies emphasizing that epidemic prevention is unrealistic unless international travel is almost fully restricted [10].
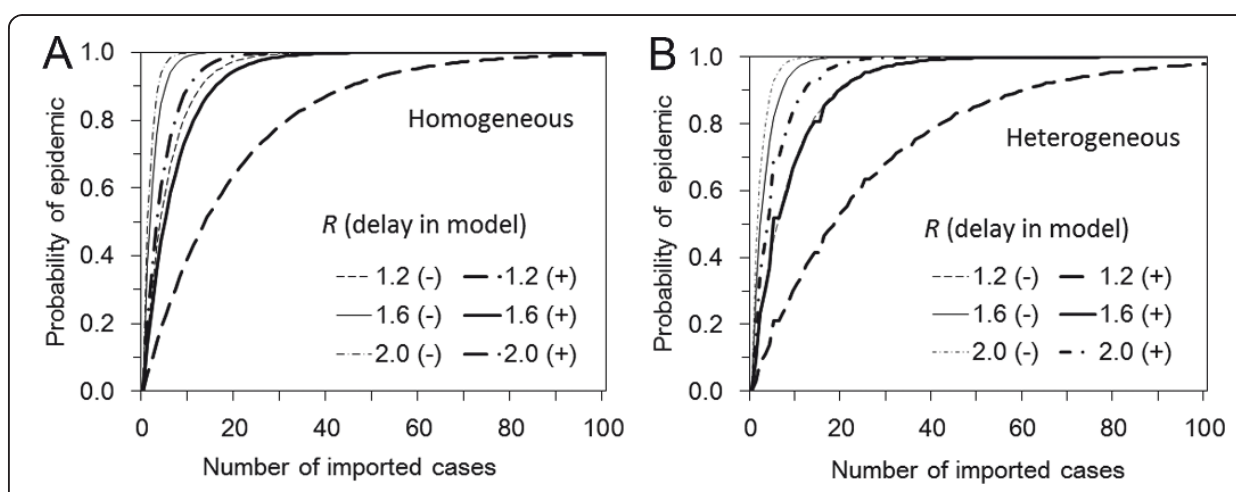

Figure 1 The probability of epidemic with and without accounting for delay in infection-age among imported cases. A. The probability of epidemic is calculated as a function of the number of imported cases and the reproduction number $(\boldsymbol{R})$ for a homogeneously mixing population with $(+)$ or without (-) consideration of delay in infection-age among imported cases. B. The case of heterogeneously mixing population. 
Given a scenario with a total number of 500 infectious imported cases, Figure 2 compares the effectiveness of different travel restriction policies with different levels of restriction. In all panels A-D, no visible effect is seen as long as movement of $60 \%$ or less travelers is restricted. When considering selective travel restrictions in Figures $2 \mathrm{C}$ and 2D, both children and adults are exhausted before observing a visible decline in the probability of epidemic. However, slightly fewer restrictions are required under a child-first restriction policy to observe a reduction in the probability of an epidemic.

Based on a scenario with 10 imported cases per day for 50 days, Figure 3 shows the days at which the probability of an epidemic first exceeds pre-specified thresholds (50\% or 95\%) under different travel restriction policies and as a function of travel volume reduction. Overall, the longest delay (i.e. days at specified travel restriction minus days at 0 percent restriction) is gained by a child-first restriction policy, indicating the importance of accounting for chronological age in considering travel restriction policies. However, even at its most effective, the delay obtained by restricting all children from traveling is shorter than 10 days.

Figure 4 shows the sensitivity of the probability of epidemic and time delaying effect of child-first travel restrictions to the choice of the assortativity coefficient. Since child

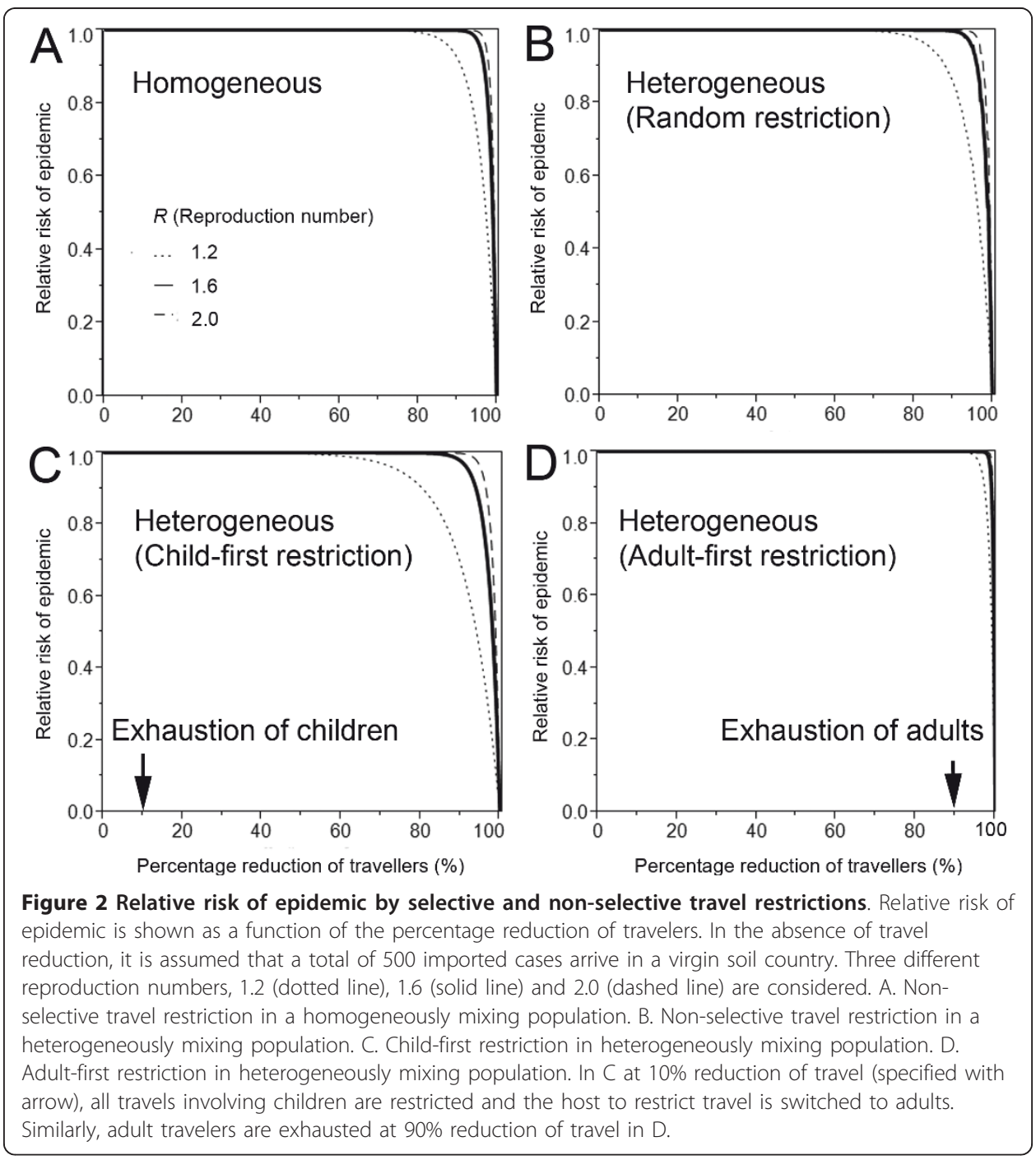




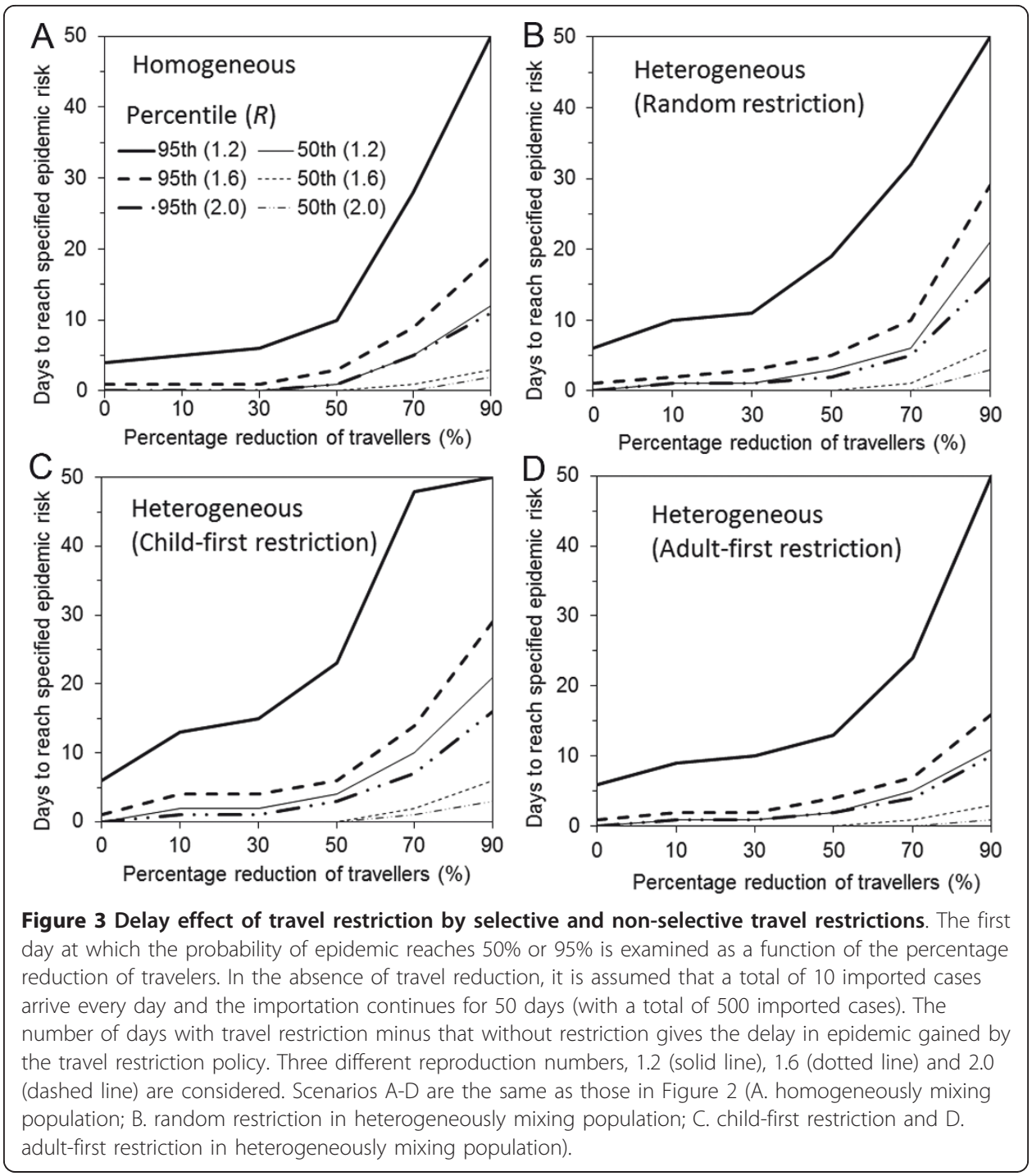

travelers are assumed to account for $10 \%$ of the total of travelers, selective restriction of child travelers of $100 \%$ corresponds to $10 \%$ restriction of the total travels. At $R=$ 1.6 (and 2.0), there was no visible decline in the probability of an epidemic (A) and the delay until a near certain epidemic (probability $>95 \%$ ) with a full child restriction policy and very high assortativity $(\theta=0.90)$ was shorter than 15 days $(C)$. In a less contagious scenario $(R=1.2)$, only a small decline in the probability of an epidemic was observed with strong assortativity and full child restriction (B). For the range of $R$ and $\theta$ examined, notable delays in median and 95 percentile points for approximately 19 days and 35 days were observed only with a specific combination of parameters, i.e., $R=1.2$ and $\theta=0.90$ (D). Neither a decline in the probability nor a delay to the start of the epidemic was visible with other parameter settings with smaller $\theta$.

\section{Discussion}

The present study examined the effectiveness of selective travel restriction on a heterogeneously mixing population, focusing on full travel restriction among children. The analysis was motivated by two realistic public health issues: (i) children acted as the 


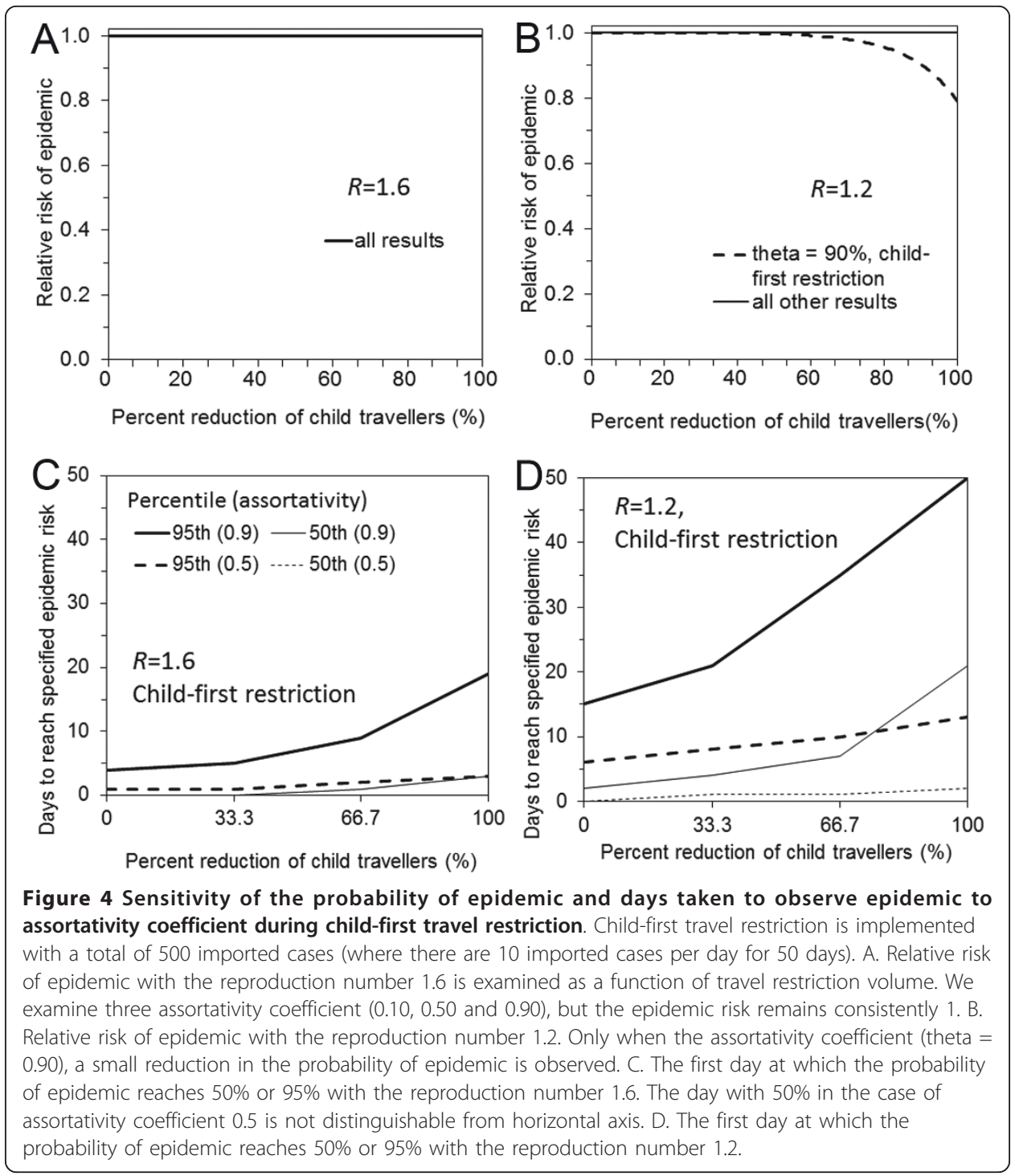

host maintaining transmission of influenza H1N1-2009 pandemic while adults were relatively less important in transmission [29-32] and (ii) the restriction of all international travel is economically damaging, but restricting child travel (e.g. by cancelling school trips) may be more politically feasible and less damaging to the global and local economies. As was expected, preferentially restricting child travels would be more effective than ignoring age or restricting adults. However, our analysis suggests that such a policy would have marginal public health benefits, only slightly reducing the risk of the outbreak in the short term or delaying the outbreak by a few weeks at best. With all but low transmission potential and low degrees of assortativity, selective travel restrictions offer neither a real reduction in the probability of epidemic nor a substantial delay until it takes off.

The effectiveness of selective travel restrictions has not heretofore attracted scientific attention prior to the H1N1-2009 pandemic, although frequent flyers and their role in facilitating international spread have been closely examined [6]. Many published studies mainly focused on detailed spatial dynamics of transmission in relation to travel 
restrictions, finding for instance that more than $99 \%$ of infected travelers have to refrain from traveling to yield substantial preventive effects $[7,9,10]$. Given the role of children in propagating H1N1-2009 [13-15] (summarized in Table 2) and considering the potential to put child-only restrictions into practice, we considered age as an important component to determine the effectiveness of travel restrictions and focused on capturing the role of age-dependency on the mechanism of invasion. Our results indicated that while the effectiveness would be marginally sensitive to assortativity, it would not be substantially effective even with high assortivity.

We make several assumptions in this paper and highlight the most important ones. First, we capture the heterogeneities of transmission networks by stratifying over age but not space. As a result, our findings are conservative in the sense that the actual effectiveness of age-structured restrictions may well be slightly greater than those presented here. However, as long as adults can also contribute to generating local child secondary cases, it is natural that adult travel will eventually lead to an epidemic and substantial involvement of adults in transmission would not delay the outbreak substantially.

Second, since our study rests on a simple statistical model, it has a number of further limitations. We describe the generation time distribution via a one-parameter family and it is possible that allowing a second parameter, in making the distribution more realistic, may potentially elevate the probability of extinction [23,33]. Furthermore, it should be remembered that the success of travel restriction depends on travel volume, and this can substantially vary across the world. We examined a plausible number of 10 imported cases per day for the first 50 days through a single port of entry, the scenario most likely to allow effective border closures, but countries with much fewer importations can potentially expect some naturally-occurring delay (e.g. small island nations in Melanesia). Moreover, big countries with multiple ports of entry (e.g. USA and Australia), countries with unmonitored land borders (e.g. those within the Schengen area) and shorter distance of school trip among school-age children as compared to intercontinental travel by adults could prevent the implementation of such a strategy even if it were effective in territories such as Hong Kong. To improve our understanding of this subject further, it might be valuable to account for more detailed heterogeneity (e.g. household and community) and other outcome measurements (e.g. timing and height of epidemic peak), as well as the additional effect of entry screening policies on top of travel restrictions [34], which would help further our understanding of the effectiveness of travel restrictions in realistic settings. Moreover, we should be able to estimate and compare the cost of available policy options. To help relevant policy decisions in the future, we would need more objective epidemiological criteria concerning the severity of disease or an imminent public health risk by elaborating epidemiological details of descriptions given in International Health Regulations $[12,35]$. The decision may also depend on other available options of control (e.g. if it were realistic to contain an outbreak at local levels, we would not need travel restrictions).

Despite the presence of various realistic features to be explored, the present study has demonstrated that a key policy question can be answered at least qualitatively using a simple statistical model. In conclusion, selective travel restriction of child travelers would have minimal impact on the risk and timeline of an outbreak, even in 
scenarios most favorable to this strategy. Our findings add to the growing body of evidence that travel restrictions are not viable public health solutions in the face of an emergent influenza pandemic.

\title{
List of abbreviations
}

$R$ : the reproduction number.

\section{Acknowledgements}

This work received financial support from the Research Fund for the Control of Infectious Disease, Food and Health Bureau, Government of the Hong Kong Special Administrative Region (grant no. HK-11-04-01), the Harvard Center for Communicable Disease Dynamics from the National Institute of General Medical Sciences (grant no. U54 GM088558), the Area of Excellence Scheme of the Hong Kong University Grants Committee (grant no. AoE/M-12/06), and the JST PRESTO program. The funding bodies were not involved in the collection, analysis and interpretation of data, the writing of the manuscript or the decision to submit for publication.

\author{
Author details \\ 'School of Public Health, The University of Hong Kong, Level 6, Core F, Cyberport 3, 100 Cyberport Road, Pokfulam, \\ Hong Kong, People's Republic of China. ${ }^{2}$ Saw Swee Hock School of Public Health, National University of Singapore, \\ Singapore. ${ }^{3}$ Department of Statistics and Applied Probability, National University of Singapore, 117546 Singapore. \\ ${ }^{4}$ Duke-NUS Graduate Medical School, 169857, Singapore. ${ }^{5}$ PRESTO, Japan Science and Technology Agency, Honcho 4- \\ 1-8, Kawaguchi, Saitama, 332-0012, Japan.
}

\section{Authors' contributions}

HN conceived of the study and developed methodological ideas. EHYL and HN implemented statistical analyses and drafted the manuscript. JYTW and MSYL contributed to statistical modeling. BJC and ARC gave comments on earlier draft and helped improve the manuscript. All authors read and approved the final manuscript.

\section{Competing interests}

BJC reports receiving research grant funding from MedImmune Inc., a manufacturer of influenza vaccines. All other authors declare that they have no competing interests.

Received: 23 September 2011 Accepted: 11 November 2011 Published: 11 November 2011

\section{References}

1. Khan K, Arino J, Hu W, Raposo P, Sears J, Calderon F, Heidebrecht C, Macdonald M, Liauw J, Chan A, Gardam M: Spread of a novel influenza A (H1N1) virus via global airline transportation. N Engl J Med 2009, 361:212-214.

2. Neumann G, Noda T, Kawaoka Y: Emergence and pandemic potential of swine-origin H1N1 influenza virus. Nature 2009, 459:931-939.

3. Roberts MG, Nishiura H: Early estimation of the reproduction number in the presence of imported cases: pandemic influenza H1N1-2009 in New Zealand. PLoS One 2011, 6:e17835.

4. Paine S, Mercer GN, Kelly PM, Bandaranayake D, Baker MG, Huang QS, Mackereth G, Bissielo A, Glass K, Hope V: Transmissibility of 2009 pandemic influenza $A(\mathrm{H} 1 \mathrm{~N} 1)$ in New Zealand: effective reproduction number and influence of age, ethnicity and importations. Euro Surveill 2010, 15, pii = 19591.

5. Scalia Tomba G, Wallinga J: A simple explanation for the low impact of border control as a countermeasure to the spread of an infectious disease. Math Biosci 2008, 214:70-72.

6. Hollingsworth TD, Ferguson NM, Anderson RM: Frequent travelers and rate of spread of epidemics. Emerg Infect Dis 2007, 13:1288-1294.

7. Hollingsworth TD, Ferguson NM, Anderson RM: Will travel restrictions control the international spread of pandemic influenza? Nat Med 2006, 12:497-499.

8. Epstein JM, Goedecke DM, Yu F, Morris RJ, Wagener DK, Bobashev GV: Controlling pandemic flu: the value of international air travel restrictions. PLOS One 2007, 2:e401.

9. Eichner M, Schwehm M, Wilson N, Baker MG: Small islands and pandemic influenza: potential benefits and limitations of travel volume reduction as a border control measure. BMC Infect Dis 2009, 9:160.

10. Cooper BS, Pitman RJ, Edmunds WJ, Gay NJ: Delaying the international spread of pandemic influenza. PLoS Med 2006, 3:e212.

11. Bell DM, World Health Organization Writing Group: Non-pharmaceutical interventions for pandemic influenza, international measures. Emerg Infect Dis 2006, 12:81-87.

12. World Health Organization: International Health Regulations, 2005 Geneva, World Health Organization; 2005 [http://www. who.int/ihr/en/], [last accessed on 9 August 2011].

13. Fraser C, Donnelly CA, Cauchemez S, Hanage WP, Van Kerkhove MD, Hollingsworth TD, Griffin J, Baggaley RF, Jenkins HE, Lyons EJ, Jombart T, Hinsley WR, Grassly NC, Balloux F, Ghani AC, Ferguson NM, Rambaut A, Pybus OG, Lopez-Gatell H, Alpuche-Aranda CM, Chapela IB, Zavala EP, Guevara DM, Checchi F, Garcia E, Hugonnet S, Roth C, WHO Rapid Pandemic Assessment Collaboration: Pandemic potential of a strain of influenza A (H1N1): early findings. Science 2009, 324:1557-1561.

14. Nishiura H, Chowell G, Safan M, Castillo-Chavez C: Pros and cons of estimating the reproduction number from early epidemic growth rate of influenza A (H1N1) 2009. Theor Biol Med Model 2010, 7:1.

15. Cowling BJ, Chan KH, Fang VJ, Lau LL, So HC, Fung RO, Ma ES, Kwong AS, Chan CW, Tsui WW, Ngai HY, Chu DW, Lee PW, Chiu MC, Leung GM, Peiris JS: Comparative epidemiology of pandemic and seasonal influenza A in households. N Engl J Med 2010, 362:2175-2184. 
16. Chen MI, Lee VJ, Lim WY, Barr IG, Lin RT, Koh GC, Yap J, Cui L, Cook AR, Laurie K, Tan LW, Tan BH, Loh J, Shaw R, Durrant C, Chow VT, Kelso A, Chia KS, Leo YS: 2009 influenza A(H1N1) seroconversion rates and risk factors among distinct adult cohorts in Singapore. JAMA 2010, 303:1383-1391.

17. Nishiura H, Oshitani H: Household transmission of influenza (H1N1-2009) in Japan: age-specificity and reduction of household transmission risk by zanamivir treatment. J Int Med Res 2011, 39:619-628.

18. Nishiura H: Travel and age of influenza A (H1N1) 2009 virus infection. J Trav Med 2010, 17:269-270.

19. Nishiura H, Cook AR, Cowling BJ: Assortativity and the Probability of Epidemic Extinction: A Case Study of Pandemic Influenza A (H1N1-2009). Interdiscip Perspect Infect Dis 2011, 2011:194507.

20. Omori $\mathrm{R}$, Nishiura $\mathrm{H}$ : Theoretical basis to measure the impact of short-lasting control of an infectious disease on the epidemic peak. Theor Biol Med Model 2011, 8:2.

21. Mukherjee P, Lim PL, Chow A, Barkham T, Seow E, Win MK, Chua A, Leo YS, Cheng Chen MI: Epidemiology of travelassociated pandemic (H1N1) 2009 infection in 116 patients, Singapore. Emerg Infect Dis 2010, 16:21-26.

22. Ministry of Justice, Japan: Annual Report of Statistics on Legal Migrants, 2010 Tokyo, Ministry of Justice, Japan; 2011 [http://www.immi-moj.go.jp/toukei/], [last accessed on 4 November 2011].

23. Nishiura $\mathrm{H}$, Yan P, Sleeman CK, Mode CJ: Estimating the transmission potential of supercritical processes based on the final size distribution of minor outbreaks. J Theor Biol 2012, 294:48-55.

24. Boëlle PY, Ansart S, Cori A, Valleron AJ: Transmission parameters of the A/H1N1 (2009) influenza virus pandemic: a review. Influenza Other Respi Viruses 2011, 5:306-316.

25. Griffiths DA: Multivariate birth-and-death processes as approximations to epidemic processes. J Appl Prob 1973, 10:15-26.

26. Nishiura H, Wilson N, Baker MG: Quarantine for pandemic influenza control at the borders of small island nations. BMC Infect Dis 2009, 9:27.

27. Caley P, Becker NG, Philp DJ: The waiting time for inter-country spread of pandemic influenza. PLoS One 2007, 2 e143.

28. Mossong J, Hens N, Jit M, Beutels P, Auranen K, Mikolajczyk R, Massari M, Salmaso S, Tomba GS, Wallinga J, Heijne J, Sadkowska-Todys M, Rosinska M, Edmunds WJ: Social contacts and mixing patterns relevant to the spread of infectious diseases. PLoS Med 2008, 5:e74

29. Medlock J, Galvani AP: Optimizing influenza vaccine distribution. Science 2009, 325:1705-1708.

30. Knipl DH, Röst G: Modelling the strategies for age specific vaccination scheduling during influenza pandemic outbreaks. Math Biosci Eng 2011, 8:123-139.

31. Ng S, Wu P, Nishiura H, Ip DK, Lee ES, Cowling BJ: An analysis of national target groups for monovalent 2009 pandemic influenza vaccine and trivalent seasonal influenza vaccines in 2009-10 and 2010-11. BMC Infect Dis 2011, 11:230.

32. Klick B, Nishiura H, Ng S, Fang VJ, Leung GM, Peiris JS, Cowling BJ: Transmissibility of seasonal and pandemic influenza in a cohort of households in Hong Kong in 2009. Epidemiology 2011, 22:793-796.

33. Jagers P: Branching Processes with Biological Applications London, John Wiley and Sons; 1975.

34. Cowling BJ, Lau LL, Wu P, Wong HW, Fang VJ, Riley S, Nishiura H: Entry screening to delay local transmission of 2009 pandemic influenza A (H1N1). BMC Infect Dis 2010, 10:82.

35. Nishiura H, Kamiya K: Fever screening during the influenza (H1N1-2009) pandemic at Narita International Airport, Japan. BMC Infect Dis 2011, 11:111.

36. Fielding JE, Higgins N, Gregory JE, Grant KA, Catton MG, Bergeri I, Lester RA, Kelly HA: Pandemic H1N1 influenza surveillance in Victoria, Australia, April - September, 2009. Euro Surveill 2009, 14(42), pii $=19368$.

37. First A/H1N1 Flu Case Detected in Chile's Quake-hit Area:[http://english.cri.cn/6966/2010/03/27/45s559557.htm], (last accessed on 3 August 2011).

38. France 24 International News: Argentina and Brazil identify first flu cases. France: France 24 News; $[$ http://www. france24.com/en/20090508-argentina-brazil-identify-first-flu-cases-], (last accessed on 3 August 2011).

39. Bin C, Xingwang L, Yuelong S, Nan J, Shijun C, Xiayuan X, Chen W, National Influenza A Pandemic (H1N1) 2009 Clinical Investigation Group: National Influenza A Pandemic (H1N1) 2009 Clinical Investigation Group: Clinical and epidemiologic characteristics of 3 early cases of influenza A pandemic (H1N1) 2009 virus, People's Republic of China. Emerg Infect Dis 2009, 15:1418-1422.

40. First Case of A (H1N1):[http://www.hoy.com.ec/noticias-ecuador/cierran-colegio-de-guayaquil-por-amenaza-de-gripeah1n1-348654.html], (last accessed on 3 August 2011).

41. Sante Medecine: Deux nouveaux cas de grippe A (H1N1) en France.[http://sante-medecine.commentcamarche.net/ news/109060-deux-nouveaux-cas-de-grippe-a-h1n1-en-france], (last accessed on 3 August 2011).

42. Lisena F, Bordi L, Carletti F, Castilletti C, Ferraro F, Lalle E, Lanini S, Ruscitti LE, Fusco FM: Influenza A (H1N1) in Rome, Italy in family: three case reports. Cases J 2009, 2:9123.

43. Swine Flu Sickens 21 High School Students in Japan (Update2):[http://www.bloomberg.com/apps/news? pid=newsarchive\&sid=aUHHHwumx0ws\&refer=Europe], (last accessed on 3 August 2011).

44. Nishiura $\mathrm{H}$, Wilson $\mathrm{N}$, Baker M: Estimating the reproduction number of the novel influenza A virus (H1N1) in a Southern Hemisphere setting: preliminary estimate in New Zealand. N Z Med J 2009, 122(1299):73-77.

45. Criança com gripe viajou do Canadá:[http://www.cmjornal.xl.pt/noticia.aspx?contentid=0B34FC39-52D7-4E43-8655 ED3AE49A1A16\&channelid=F48BA50A-0ED3-4315-AEFA-86EE9B1BEDFF], (last accessed on 3 August 2011).

46. Ministry of Health, Singapore: MOH - 8th Confirmed Case of Influenza A (H1N1-2009). Singapore: Ministry of Health, Singapore;[http://app.crisis.gov.sg/InfluenzaA/Press.aspx?id = 41], (last accessed on 3 August 2011).

47. Confirmados 13 casos de gripe A entre los niños evacuados del campamento de la Vera:[http://www.vivenavalmoral. com/t/centrales-2/o/confirmados-13-casos-de-gripe-a-entre-los-nios-evacuados-del-campamento-de-la-vera-406], (last accessed on 3 August 2011).

48. lamsirithaworn S, Akarasewi P, Yingyong T, Suthachana S, Pittayawonganon C, Ungchusak K: Three Waves of the 2009 H1N1 Influenza Pandemic in Thailand. Siriraj Med J 2011, 63(2):64-67.

49. Kar-Purkayastha I, Ingram C, Maguire $H$, Roche A: The importance of school and social activities in the transmission of influenza A(H1N1)v: England, April - June 2009. Euro Surveill 2009, 14(33)[http://www.eurosurveillance.org/ ViewArticle.aspx?Articleld=19311], pii = 19311, (last accessed on 3 August 2011). 
50. Anonymous: Swine Influenza A (H1N1) Infection in Two Children-Southern California, March-April 2009. Mortal Morbid Wkly Rep 2009, 58:1-3.

51. Sydney Morning Herald, Australia. Second wave of swine flu to hit:[http://www.smh.com.au/national/second-wave-ofswine-flu-to-hit-20100206-njv1.html], (last accessed on 3 August 2011).

52. Department of health and ageing, Australia: Australian influenza report 2009 - 16 to 29 May 2009. Australia: Department of health and ageing; [http://www.health.gov.au/internet/main/publishing.nsf/Content/cda-ozflu-29-5-09. htm], (last accessed on 3 August 2011).

53. Echavarría M, Querci M, Marcone D, Videla C, Martínez A, Bonvehi P, Carballal G: Pandemic (H1N1) 2009 cases, Buenos Aires, Argentina. Emerg Infect Dis 2010, 16(2):311-313.

54. Koliou M, Soteriades ES, Toumasi MM, Demosthenous A, Hadjidemetriou A: Epidemiological and clinical characteristics of influenza $A(\mathrm{H} 1 \mathrm{N1}) v$ infection in children: The first 45 cases in Cyprus, June - August 2009. Euro Surveill 2009, 14(33)[http://www.eurosurveillance.org/NiewArticle.aspx?Articleld=19312], pii = 19312, (last accessed on 3 August 2011).

55. Guinard A, Grout L, Durand C, Schwoebel V: Outbreak of influenza $A(\mathrm{H} 1 \mathrm{~N} 1) v$ without travel history in a school in the Toulouse district, France, June 2009. Euro Surveill 2009, 14(27)[http://www.eurosurveillance.org/ViewArticle.aspx? Articleld=19265], pii = 19265, (last accessed on 3 August 2011).

56. Novel influenza $A(H 1 N 1)$ investigation team: Description of the early stage of pandemic (H1N1) 2009 in Germany, 27 April-16 June 2009. Euro Surveill 2009, 14(31)[http://www.eurosurveillance.org/NiewArticle.aspx?Articleld=19295], pii = 19295, (accessed on 3 August 2011).

57. Japan confirms 96 H1N1 flu cases, most are students:[http://thestar.com.my/news/story.asp?file=/2009/5/18/ worldupdates/2009-05-18T090420Z_01_NOOTR_RTRMDNC_0_-396888-1\&sec=Worldupdates], (last accessed on 3 August 2011).

58. Macao Reports 6 New A/H1N1 Confirmed Cases:[http://english.cri.cn/6909/2009/07/01/1261s498178.htm], (last accessed on 3 August 2011).

59. Lee KC: Influenza A/H1N1 Pandemic: The Scare of 2009. Malaysian J Med Sci 2009, 16(3):1-3.

60. Lessler J, Reich NG, Cummings DAT and the New York City Department of Health and Mental Hygiene Swine Influenza Investigation Team: Outbreak of 2009 pandemic influenza A (H1N1) at a New York City school. N Engl J Med 2009, 361:2628-2636

doi:10.1186/1742-4682-8-44

Cite this article as: Lam et al:: The feasibility of age-specific travel restrictions during influenza pandemics.

Theoretical Biology and Medical Modelling 2011 8:44

\section{Submit your next manuscript to BioMed Central and take full advantage of:}

- Convenient online submission

- Thorough peer review

- No space constraints or color figure charges

- Immediate publication on acceptance

- Inclusion in PubMed, CAS, Scopus and Google Scholar

- Research which is freely available for redistribution 